\title{
Response of Mediterranean Synechococcus growth and loss rates to experimental nutrient inputs
}

\author{
Nona S. R. Agawin*, Carlos M. Duarte, Susana Agustí \\ Instituto Mediterraneo de Estudios Avanzados (CSIC-UIB), C/Miquel Marqués 21, 07190 Esporles, \\ Mallorca, Spain
}

\begin{abstract}
The response of Synechococcus sp. growth, primary production and loss rates was examined in a large-scale mesocosm nutrient enrichment experiment in a coastal NW Mediterranean bay community during the summer of 1997. The mesocosm units $\left(33 \mathrm{~m}^{3}\right)$ received N, P and Si at a stochiometric ratio of $20 \mathrm{~N}: 7 \mathrm{Si}: 1 \mathrm{P}$, at the normal nutrient loading rate for the site $\left(5 \mathrm{mmol} \mathrm{N} \mathrm{m}^{-2} \mathrm{~d}^{-1}\right)$, and at $0.5-, 2-, 4-, 8-$, and 16 -fold the normal nutrient loading input into the bay. Growth and primary production of Synechococcus during the early phase of the experiment increased 2- to 4 -fold in the mesocosms receiving $\geq 4$-fold the normal nutrient loading rate compared to those receiving less, providing evidence of nutrient-limited growth of the population in the Mediterranean bay studied during that summer. Synechococcus growth was saturated at approximately $0.25 \mu \mathrm{M}$ DIN, and was unsustained as nutrient inputs continued, showing growth inhibition at relatively high DIN levels $(>8 \mu \mathrm{M})$. The response of loss rates of Synechococcus to the experimental nutrient inputs was similar to the growth responses, although the dynamics of Synechococcus population size seemed to be an interplay between growth and loss rates. The population size of Synechococcus increased early by almost 3-fold, indicative of limitation of Synechococcus biomass in the Bay of Blanes during summer. The increase is suggested to result from the lag between Synechococcus growth and loss rate responses during the early phase of the experiment when growth rates exceeded loss rates, resulting in an increase in net production with increased loading. The increase of Synechococcus population size towards the end of the experiment was a result of decreased grazing pressure on Synechococcus, despite the low growth rates of Synechococcus at the high nutrient inputs. Grazing of Synechococcus is suggested to be the main loss process ( $>50 \%$ of calculated loss rates) except towards the end of the experiment when grazing was only $13 \%$ of the calculated losses.
\end{abstract}

KEY WORDS: Synechococcus sp. growth and loss rates $\cdot$ Nutrient inputs $\cdot$ Mediterranean coastal area $\cdot$ Mesocosm experiments

\section{INTRODUCTION}

Picophytoplankton contribute up to $39 \%$ of the planktonic primary production in the global ocean (Agawin et al. 2000), and are most important in warm, oligotrophic waters (Peña et al. 1990, Chisholm 1992, Agawin et al. 2000). Recent evidence suggests that

*E-mail: ieanar@clust.uib.es picophytoplankton dominate in waters with nutrient $\left(\mathrm{NO}_{3}+\mathrm{NO}_{2}\right)$ concentrations $<1 \mu \mathrm{M}$. At higher concentrations, the contribution of picophytoplankton to total biomass and production significantly declines (Agawin et al. 2000). Picophytoplankton are expected to be able to sustain relatively fast growth rates in oligotrophic waters due to their high specific affinity for nutrients associated with their small size (Chisholm 1992, Thingstad 1998). The maintenance of the fast growth rate of marine picophytoplankton in warm oligotrophic 
waters (up to $2 \mathrm{~d}^{-1}$, Agawin et al. 1998), would theoretically require minimum DIN concentrations of about $0.4 \mathrm{nM} \mathrm{P}$ and $7 \mathrm{nM} \mathrm{N}$ (Agawin et al. 2000), which are below the detection limits of standard analytical methods. Picophytoplankton, therefore, are dominant in ultraoligotrophic waters (Agawin et al. 2000), where they have been suggested to grow at rates close to their potential maximum (Goldman et al. 1979, Laws et al. 1984). However, evidence of nutrient limitation in oligotrophic waters extends also to picophytoplankton (Vaulot et al. 1996, Thingstad et al. 1998). This apparent conflict may result from nutrient-dependent loss rates, expected from the overall balance between Synechococcus growth and loss rates (Agawin et al. 1998, Schlüter 1998), which may result in nutrientindependent net population growth rates even in the presence of nutrient-limited growth.

Here, we tested the response of picophytoplankton growth and loss rates to experimental nutrient additions in mesocosms moored in a coastal area in the oligotrophic NW Mediterranean Sea. We did so by examining production, growth and loss rates of the picophytoplankton community in response to a gradient of nutrient inputs to a set of large (effective volume $33 \mathrm{~m}^{3}$ ) experimental mesocosm units suspended in Blanes Bay (NE Spain). Nutrient concentrations in Blanes Bay are relatively low during summer (Duarte unpubl.), although nutrient inputs, largely attributable to coastal tourism, are estimated to be high at about $5 \mathrm{mmol} \mathrm{N} \mathrm{m}{ }^{-2} \mathrm{~d}^{-1}$ (Duarte et al. 2000a). The experiment consisted of a gradient of nutrient inputs to the mesocosms ranging from 0.5 - to 16 -fold the estimated nutrient loading rate to the Bay, and also included a mesocosm where no nutrients were added (Duarte et al. 2000a). We conducted the experiment in summer when picophytoplankton in the Bay of Blanes, dominated by Synechococcus sp., achieve its maximal growth (Agawin et al. 1998) and nutrient concentrations are low (Duarte unpubl.).

\section{METHODS}

The mesocosm experiment was conducted in a NW Mediterranean bay (Bay of Blanes, $41^{\circ} 39.90^{\prime} \mathrm{N}$, $2^{\circ} 48.03^{\prime}$ E) during summer (June 18 to July 8, 1997). The experiment consisted of 7 mesocosms (14 m high, $4.2 \mathrm{~m}^{2}$ cross-sectional area, with an effective volume of $33 \mathrm{~m}^{3}$ ) suspended from a platform moored at a site $1 \mathrm{~km}$ offshore from the Bay of Blanes at a depth of $35 \mathrm{~m}$. Further details of the experimental design are provided by Duarte et al. (2000a). Briefly, the mesocosms received a gradient of nutrient inputs, from no nutrient input, except atmospheric ones, to $10.18 \mu \mathrm{M} \mathrm{N}$ $\mathrm{d}^{-1}$, exceeding the calculated nutrient loading to the
Bay of Blanes 16-fold (Duarte et al. 2000a). The estimated summer loading to the Bay of Blanes corresponded to the mesocosm unit receiving $0.64 \mu \mathrm{M} \mathrm{N} \mathrm{d}^{-1}$. Nitrogen, phosphorus and silicon were added at a constant ratio (20N : $7 \mathrm{Si}: 1 \mathrm{P})$, close to the average nutrient ratio in the nutrient loading to Blanes Bay (Duarte et al. 2000a). The nutrients were added as $\mathrm{NH}_{4} \mathrm{Cl}(\mathrm{N})$, $\mathrm{KH}_{2} \mathrm{PO}_{4}(\mathrm{P})$, and $\mathrm{Na}_{2} \mathrm{SiF}_{6}$ (Si) every other day during the $21 \mathrm{~d}$ span of the experiment. Nutrients were added by filling a tube extending from the water surface to the bottom of the mesocosms, which was slowly withdrawn to ensure homogenous mixing and distribution along the water column. Integrated water samples of 501 were collected on alternate days for biological and chemical (dissolved nutrient concentrations) analyses.

Primary production, growth and losses. Primary production of the $<2 \mu \mathrm{m}$ fraction was determined for each mesocosm every 4 to $5 \mathrm{~d}$ from the beginning of the experiment. For each nutrient level, a subsample $(500 \mathrm{ml})$ was filtered through $2 \mu \mathrm{m}$ (pore size) polycarbonate filters. Approximately $93 \%$ of the picophytoplankton population (dominated by Synechococcus sp., ca $99 \%$ of the community) passed through the $2 \mu \mathrm{m}$ PC filters (Agawin et al. 2000). Three (2 clear and 1 dark) $125 \mathrm{ml}$ PC Nalgene bottles were each filled with $120 \mathrm{ml}$ of the $<2 \mu \mathrm{m}$ fraction, while another set of 3 bottles were filled with whole seawater from the same mesocosm. One $\mathrm{ml}$ of ${ }^{14} \mathrm{C}$ solution in varying concentrations $(23,20,15,10,5 \mu \mathrm{Ci}$, depending on the expected carbon uptake), was added to each bottle. The light bottles were incubated at $200 \mu \mathrm{E} \mathrm{m}^{-2} \mathrm{~s}^{-1}$, and placed, along with the dark bottles, in an incubator chamber with temperature control (adjusted to the in situ water temperature). After $3 \mathrm{~h}$ of incubation, samples were filtered through $0.45 \mu \mathrm{m}$ Millipore filters, and filters were fumed over concentrated $\mathrm{HCl}$ to remove traces of inorganic C. Radioactivity on the filters was measured with a liquid scintillation counter with correction for quenching. All materials were acidcleaned prior to use. Primary production, in the form of carbon uptake in hourly rates, was converted to daily rates by multiplying by 14 daylight hours. The calculated daily production rates may deviate from in situ obtained values because the in situ light condition was not simulated in the incubator chambers. However, we expected the deviations to be minimal since the average underwater irradiance exceeded, during most of the day, the values needed to saturate photosynthesis of the plankton community $\left(<200 \mu \mathrm{E} \mathrm{m}^{-2} \mathrm{~s}^{-1}\right.$ in summer, Satta et al. 1996).

Synechococcus biovolume was calculated as the product of abundance and average cell volume. The abundance and cell volume of Synechococcus were determined by flow cytometric analysis of fresh, unfractionated samples with a FACSCalibur (Becton- 
Dickinson) flow cytometer according to population fluorescence and light scatter characteristics, as reported in Vaulot et al. (1990). The abundance of Synechococcus passing through the $2 \mu \mathrm{m}$ filter was determined to be $93 \%$ of the abundance in unfractionated samples. Cell volume was calculated from the forward scatter (FSC) data of the Synechococcus cells, calibrated using fluorescent beads of various sizes (Fluospheres Size Kit \# 2, Molecular Probes Co.) (Agustí et al. unpubl.). The accuracy of the estimates was confirmed by analyzing algal cultures of known sizes, determined from epifluorescent microscope measurements (Synechococcus sp., $1.3 \mu \mathrm{m}$ cell diameter, and Chlorella sp., $2.7 \mu \mathrm{m}$ cell diameter) together with latex beads of various sizes $(0.5$ to $4.5 \mu \mathrm{m})$ used in the calibrations. A Synechococcus C-content of $0.123 \mathrm{pg} \mathrm{um}^{-3}$ was used in the calculations (Waterbury et al. 1986).

Specific growth rate $(\mu)$ of Synechococcus sp. was determined following Welschmeyer \& Lorenzen (1984):

$$
\mu=\frac{-\ln \left[1-\left(P \cdot t \cdot C_{\mathrm{p}}^{-1}\right)\right]}{t}
$$

where $P$ is the primary production or $\mathrm{C}$ uptake rate ( $\mathrm{mg} \mathrm{C} \mathrm{m}^{-3} \mathrm{~d}^{-1}$ ), $t$ is the duration of incubation (d), and $C_{\mathrm{p}}\left(\mathrm{mg} \mathrm{C} \mathrm{m}^{-3}\right)$ is the cell carbon present at the end of the incubation :

$$
C_{\mathrm{p}}=\Delta C+C_{0}
$$

$\Delta C$ is the carbon fixed during the incubation period, equal to $P \cdot t$. The cell carbon $\left(C_{0}\right)$ of the Synechococcus sp. population at the beginning of the incubation was determined as the product of their biovolume $\left(\mu^{3} \mathrm{~m}^{-3}\right)$

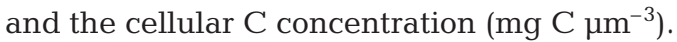

Loss rates (which would include grazing losses, mortality due to lysis, sinking losses) of Synechococcus sp. were calculated as:

$$
\text { Loss rate }\left(\mathrm{d}^{-1}\right)=\mu\left(\mathrm{d}^{-1}\right)-\operatorname{Net} \text { rate }\left(\mathrm{d}^{-1}\right)
$$

where

$$
\operatorname{Net~rate~}\left(\mathrm{d}^{-1}\right)=\frac{\ln \left(\frac{\text { abundance }_{t}}{\text { abundance }_{t-1}}\right)}{\text { Time between samples }(=2 \mathrm{~d})}
$$

Grazing experiments. Grazing experiments were carried out in mesocosm units receiving nutrient loadings of $0.64,2.54$ and $10.18 \mu \mathrm{M} \mathrm{N} \mathrm{d}^{-1}$, as well as in the mesocosm unit not receiving nutrient input on Days 2, 10 and 16. From each of the mesocosm units, a 21 seawater sample was collected, and half of it was filtered through $0.2 \mu \mathrm{m}$ filters and gently mixed with seawater to yield dilution levels of 25,50 and $75 \%$ of the natural seawater sample. From each dilution level, a 50 to $100 \mathrm{ml}$ aliquot was dispensed in duplicate dialysis bags. Additional duplicate samples of $100 \%$ natural seawater were also prepared with the remaining sample. The dialysis bag membrane had a molecular weight cut-off of 6000 to 8000 daltons, which allowed diffusion of nutrients (water residence time ca $2 \mathrm{~h}$ ), avoiding the problem of nutrient limitation which may occur in closed bottle incubations. The dialysis bags were carefully tied to a plastic wire box frame and suspended for $24 \mathrm{~h}$ inside the corresponding mesocosm units of the first experiment. In succeeding experiments, the dialysis bags were suspended in $5 \mathrm{l}$ jar bottles filled with seawater from the respective mesocosm in an incubator chamber reproducing the in situ temperature. Aquarium diffusers were placed in each jar to enhance diffusion across the dialysis membranes. Samples $(400 \mu l)$ were drawn from the dialysis bags and fixed with $10 \%$ paraformaldehyde and $0.5 \%$ glutaraldehyde and quickly frozen in liquid $\mathrm{N}_{2}$ at the initiation of the experiment and after $24 \mathrm{~h}$ of incubation. The abundance of Synechococcus was estimated using a FACSCalibur flow cytometer as described above. Grazing rate was calculated as the slope of the regression between apparent growth rates versus dilution factor (Landry \& Hassett 1982). There was generally a good linear correlation with an average $\mathrm{r}^{2}$ of the fitted regression lines $>0.5$.

Repeated ANOVA measures were used to describe the variability of the responses of Synechococcus as a function of nutrient loading applied, time and interaction effects. Comparisons were conducted using Tukey's Highest-Significant-Difference (HSD) means test (Sokal \& Rohlf 1981). Assumptions of normality and homogeneity of variances were checked using Kolmogorov-Smirnov and Bartlett's tests, respectively. Otherwise, a non-parametric Kruskal-Wallis test was used to test the response of Synechococcus. The underlying trends of responses in terms of primary production, growth and loss rates through time were described by locally weighted scatter plot smoothing (Cleveland 1979). The relationships between primary production, growth and loss rates and nutrient concentrations were fitted using the hyperbolic tangent photosynthesis-irradiance model of Jassby \& Platt (1976) and when the data showed evidence of rate inhibition at high nutrient concentrations, we used the model of Platt et al. (1980) which accounts for photo-inhibition in P-I curves to describe the inhibition of growth rates at high nutrient levels. These models were found to provide the best fits when compared to alternative models describing saturation curves. The statistical goodness-of-fit of the models was evaluated using a Kolmogorov-Smirnov 2-sample test (Sokal \& Rohlf 1981). The distribution between observed and expected values (from the model fit) at $\alpha<0.01$ did not differ significantly. 


\section{RESULTS}

DIN concentrations were very low at the start of the experiment (DIN $<0.05$ and phosphate $0.01 \mu \mathrm{M}$ ). Nutrient accumulation inside the mesocosm bags became apparent in the mesocosms receiving 4-, 8-, and 16-fold the normal loading rate in Blanes Bay, reaching up to $30 \mu \mathrm{M}$ DIN and $3 \mu \mathrm{MPO}_{4}$ at the highest input. Elevated nutrient concentrations were maintained over the first week of nutrient additions within the mesocosms receiving inputs higher than the normal loading rate in Blanes Bay, declining thereafter (Duarte et al. 2000a). In the mesocosm unit receiving only atmospheric inputs, DIN accumulated and reached $1.6 \mu \mathrm{M}$ (compared to $<0.05 \mu \mathrm{M}$ at the onset of the experiment) $2 \mathrm{wk}$ following the initiation of the experiment. These levels were comparable to DIN levels in the mesocosms receiving nutrient additions.

Abundance of Synechococcus in the mesocosms varied significantly with time and nutrient loading (Kruskal-Wallis, $\mathrm{p}<0.05$ ). Abundance was similar across mesocosms at the onset of the experiment, and increased almost 3-fold after $4 \mathrm{~d}$ of the experiment in the mesocosm units receiving the highest nutrient loadings (Fig. 1). However, the abundance of Synechococcus in the mesocosm units receiving the highest nutrient loadings rapidly declined after $1 \mathrm{wk}$ of the experiment only to increase again after $16 \mathrm{~d}$ as observed in the rest of the mesocosm units (Fig. 1).

Primary production of Synechococcus in the mesocosms varied greatly with time (ANOVA, interaction nutrient loading $\times$ time, $\mathrm{p}<0.05)$. Primary production

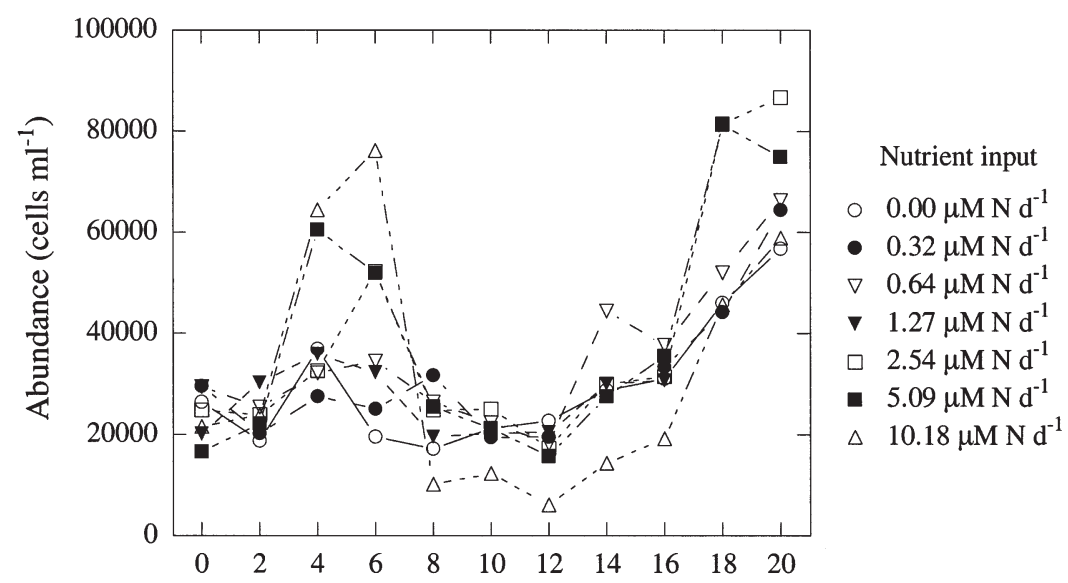

Time (days)

Fig. 1. Synechococcus. Evolution of abundance through time in the different mesocosm units receiving a gradient of nutrient loadings in the Bay of Blanes was similar across mesocosms at the onset of the experiment. After $4 \mathrm{~d}$, primary production of Synechococcus increased with increasing nutrient loadings (Fig. 2). Primary production in those mesocosms receiving 4 - to 16 -fold $\left(\geq 2.54 \mu \mathrm{M} \mathrm{N} \mathrm{d}^{-1}\right)$ the nutrient loading rate of the Bay of Blanes was 2- to 4 -fold higher ( $p<0.05$, HSD test) than those receiving lower nutrient inputs (Fig. 2). After $1 \mathrm{wk}$ of the experiment, primary production of Synechococcus still increased with increasing nutrient loadings, but only at nutrient loadings up to 2-fold the normal loading rate in the Bay of Blanes, remaining similar at nutrient loadings $\geq 2.54 \mu \mathrm{M} \mathrm{N} \mathrm{d}^{-1}$ (Fig. 2). Primary production in mesocosms receiving $\geq 2.54 \mu \mathrm{M} \mathrm{N} \mathrm{d}^{-1}$ nutrient loadings declined after $1 \mathrm{wk}$ of nutrient additions and reached values comparable to those observed at low nutrient inputs during the following week of the experiment (Fig. 2). Towards the end of the experiment, primary production of Synechococcus increased at the lowest nutrient loadings and subsequently declined as nutrient loadings exceeded, by more than 2 -fold, the normal loading rate ( $\geq 2.54 \mu \mathrm{M} \mathrm{N} \mathrm{d}^{-1}$, Fig. 2).

The growth rate of Synechococcus varied in the mesocosm bags with nutrient and time (ANOVA, interaction nutrient loading $\times$ time, $\mathrm{p}<0.05$ ). The growth rate of Synechococcus at the onset of the experiment averaged $1.17( \pm 0.2) \mathrm{d}^{-1}$ and increased after $4 \mathrm{~d}$ of nutrient loadings $\geq 2.54 \mu \mathrm{M} \mathrm{N} \mathrm{d}^{-1}$, reaching twice the initial growth rate (Fig. 2). The growth rate tended to increase with time to reach rates close to $5.0 \mathrm{~d}^{-1}$ in all mesocosms, although growth rates had declined in the units receiving the highest nutrient inputs by the end of the experiment (Fig. 2).

Loss rates were in close balance with growth rates and the responses of growth and loss rates with increasing nutrient inputs were quite similar (Fig. 2). Grazing rates on Synechococcus at the middle of the experiment (Day 10) were highest in the mesocosm receiving the highest nutrient addition, and towards the end of the experiment grazing rates were similar across the mesocosms, and relatively low compared to the results of earlier grazing experiments (Fig. 3). Grazing rates were found to be negatively correlated with Synechococcus population size $\left(r^{2}=0.62, p<0.05\right.$, Fig. 3). Grazing rates accounted for most of the calculated loss rates during the first 2 wk of the experiment (on average $>50 \%$ ), except towards the end of the experiment when grazing accounted for only $13 \%$, on average, of the calculated loss rates. 
Primary production

(mg C m ${ }^{-3} \mathrm{~d}^{-1}$ )
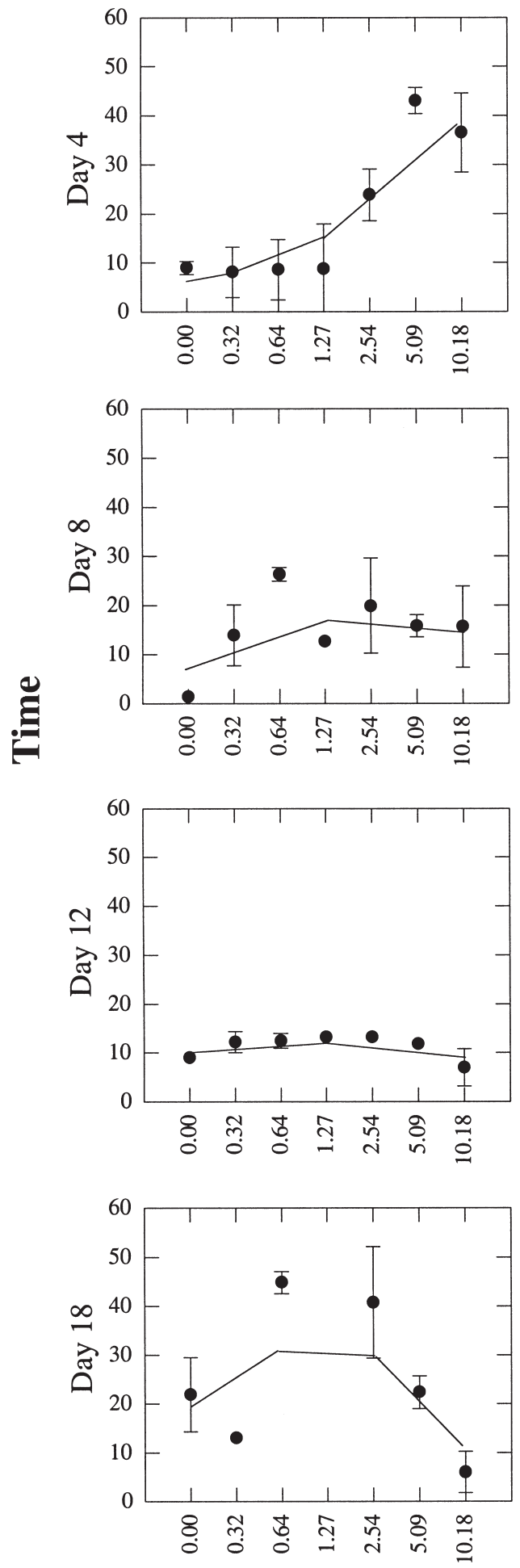

Growth rate $\left(d^{-1}\right)$
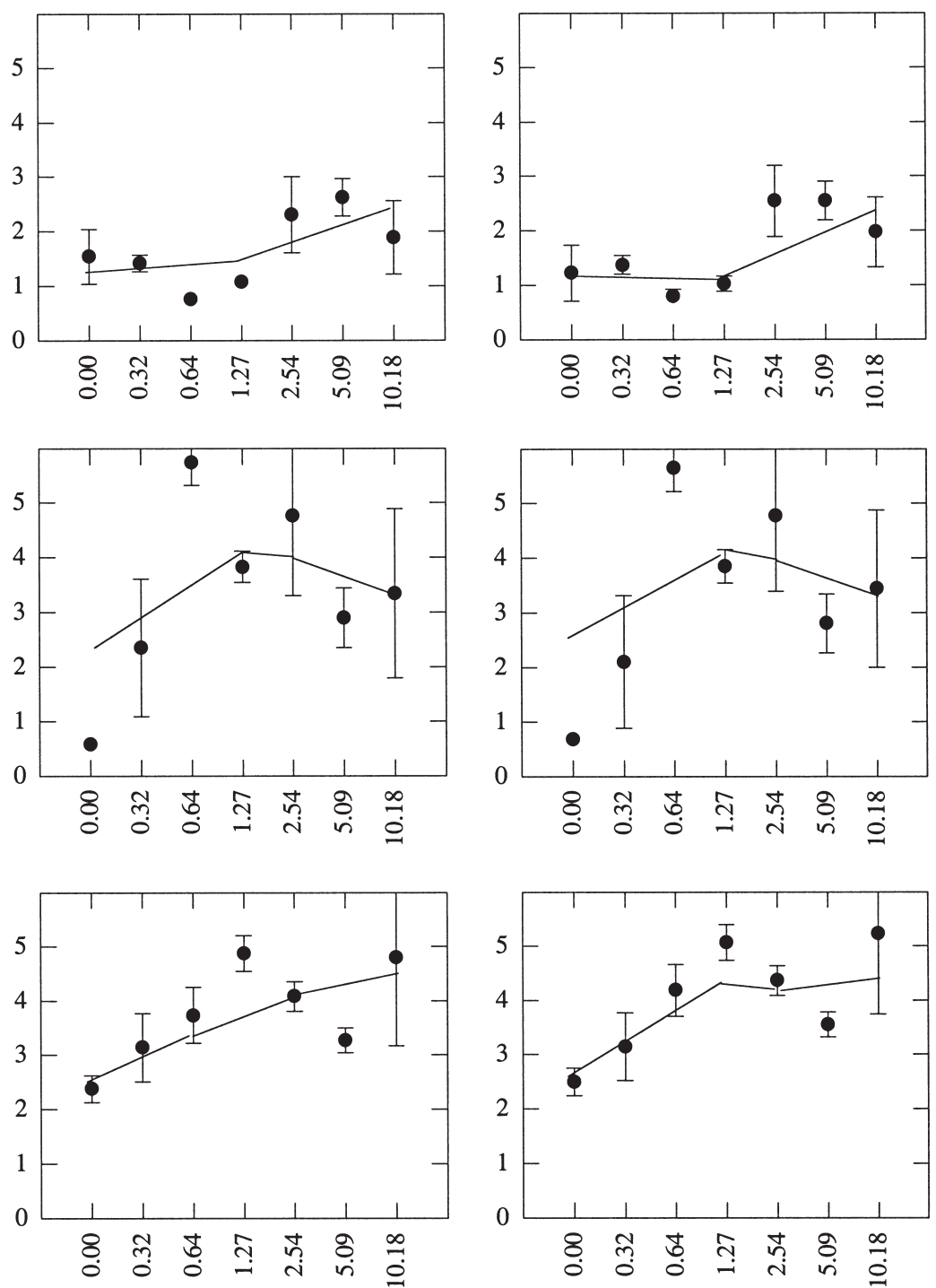

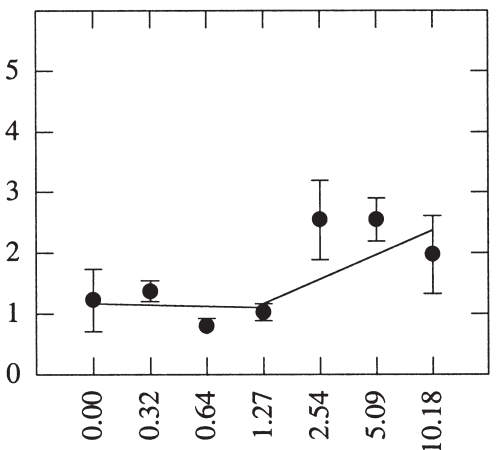

Loss rate $\left(d^{-1}\right)$
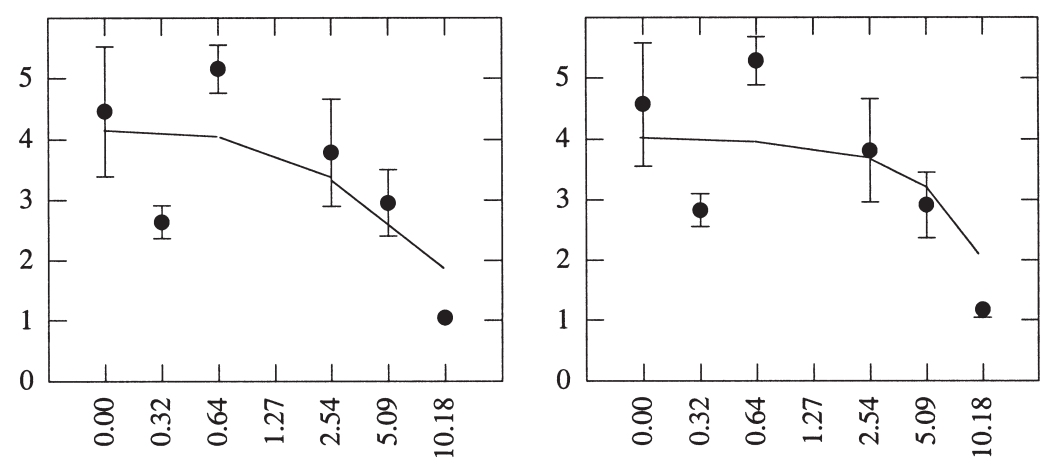

Nutrient input ( $\mu \mathrm{M} \mathrm{N} \mathrm{d^{-1 } )}$

Fig. 2. Synechococcus. Evolution of primary production, growth rates and loss rates through time in the different mesocosm units receiving a gradient of nutrient loadings in the Bay of Blanes. Error bars denote \pm SE of mean values 

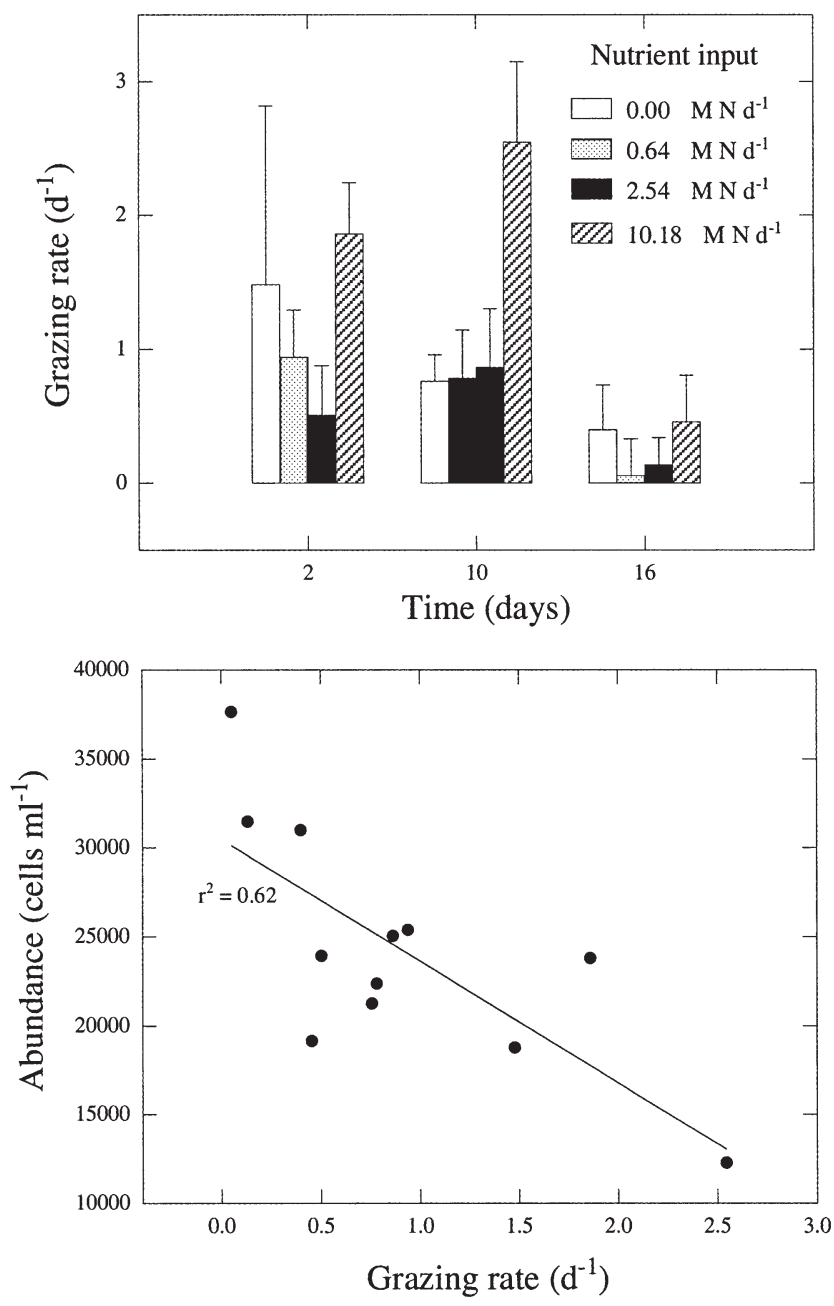

Fig. 3. Synechococcus. Mean grazing rates $( \pm \mathrm{SE})$ determined from the dilution experiments in the different mesocosm units receiving a gradient of nutrient loadings in the Bay of Blanes, and their relationship to Synechococcus population size. Solid line indicates the fitted linear regression line

The response of Synechococcus primary production to increasing DIN was best described by a hyperbolic tangent model, which also described the growth inhibition at high nutrient concentrations observed in the data (Fig. 4). The fitted equation,

$$
\begin{aligned}
& \text { Primary production }\left(\mathrm{mg} \mathrm{C} \mathrm{m} \mathrm{C}^{-3} \mathrm{~d}^{-1}\right)= \\
& 49.3 \cdot\left(1-\mathrm{e}^{\frac{-\mathrm{DIN}(\mu \mathrm{M})(14.4)}{49.3}}\right) \cdot \mathrm{e}^{\frac{-\operatorname{DIN}(\mu \mathrm{M})(1.05)}{49.3}} \\
& \left(\mathrm{r}^{2}=0.83\right)
\end{aligned}
$$

predicts the average maximum primary production of $37.8 \mathrm{mg} \mathrm{C} \mathrm{m}^{-2} \mathrm{~d}^{-1}$, to be achieved at a DIN concentration of $7.4 \mu \mathrm{M}$ (Fig. 4). Primary production of Synechococcus declined above this DIN concentration (Fig. 4).
The response of Synechococcus growth with increasing DIN was also fitted by the same model, yielding the equation,

$$
\begin{aligned}
& \text { Growth rate }\left(\mathrm{d}^{-1}\right)= \\
& 3.07 \cdot\left(1-\mathrm{e}^{\frac{-\mathrm{DIN}(\mu \mathrm{M})(33.63)}{3.07}}\right) \cdot \mathrm{e}^{\frac{-\mathrm{DIN}(\mu \mathrm{M})(0.02)}{3.07}} \\
& \left(\mathrm{r}^{2}=0.82\right)
\end{aligned}
$$

which predicts the average maximum growth rate of $3.05 \mathrm{~d}^{-1}$ occurring at a DIN concentration of $0.25 \mu \mathrm{M}$ (Fig. 4). At higher DIN concentrations, Synechococcus growth tended to decline (Fig. 4).

The relationship between Synechococcus loss rates and DIN concentration was best described by the equation,

$$
\begin{aligned}
& \text { Loss rate }\left(\mathrm{d}^{-1}\right)= \\
& 3.14 \cdot\left(1-\mathrm{e}^{\frac{-\mathrm{DIN}(\mu \mathrm{M})(34.95)}{3.14}}\right) \cdot \mathrm{e}^{\frac{-\operatorname{DIN}(\mu \mathrm{M})(0.02)}{3.14}} \\
& \left(\mathrm{r}^{2}=0.81\right)
\end{aligned}
$$

where none of the parameters differed significantly from those in the equation fitted to growth rates, indicative of the very close balance of the response of growth and loss rates $\left(\mathrm{r}^{2}=0.99, \mathrm{p}<0.05\right.$, Fig. 5) to nutrient inputs. The equation predicts average maximum loss rate of $3.12 \mathrm{~d}^{-1}$ to occur at a DIN concentration of $0.24 \mu \mathrm{M}$, declining at higher DIN concentrations (Fig. 4). Although growth and loss rates are in almost quasi-balance, growth rates exceeded loss rates at DIN concentrations $<2 \mu \mathrm{M}$ resulting in sizeable net growth rates at lower nutrient concentrations (Fig. 4).

\section{DISCUSSION}

The picophytoplankton component present in the waters at the onset of this summer experiment in the Bay of Blanes was comprised mostly of Synechococcus sp. as found by other studies in surface Mediterranean waters (Vaulot et al. 1996, Agawin et al. 1998). Prochlorococcus (Chisholm et al. 1988) was not detected here, although it seems to be present in other coastal Mediterranean areas (Vaulot et al. 1990, Jacquet et al. 1998).

Mean primary production rate (about $5.3 \mathrm{mg} \mathrm{C} \mathrm{m}^{-3}$ $\mathrm{d}^{-1}$ ) of Synechococcus at the onset of the experiment was close to the minimum values reported from different regions of the Mediterranean, in size-fractionation experiments (cf. Magazzù \& Decembrini 1995). Maximum picophytoplankton production in response to nutrient loadings was about $44.8 \mathrm{mg} \mathrm{C} \mathrm{m}^{-3} \mathrm{~d}^{-1}$ during the mesocosm experiment. This was was higher than the reported mean picophytoplankton primary produc- 

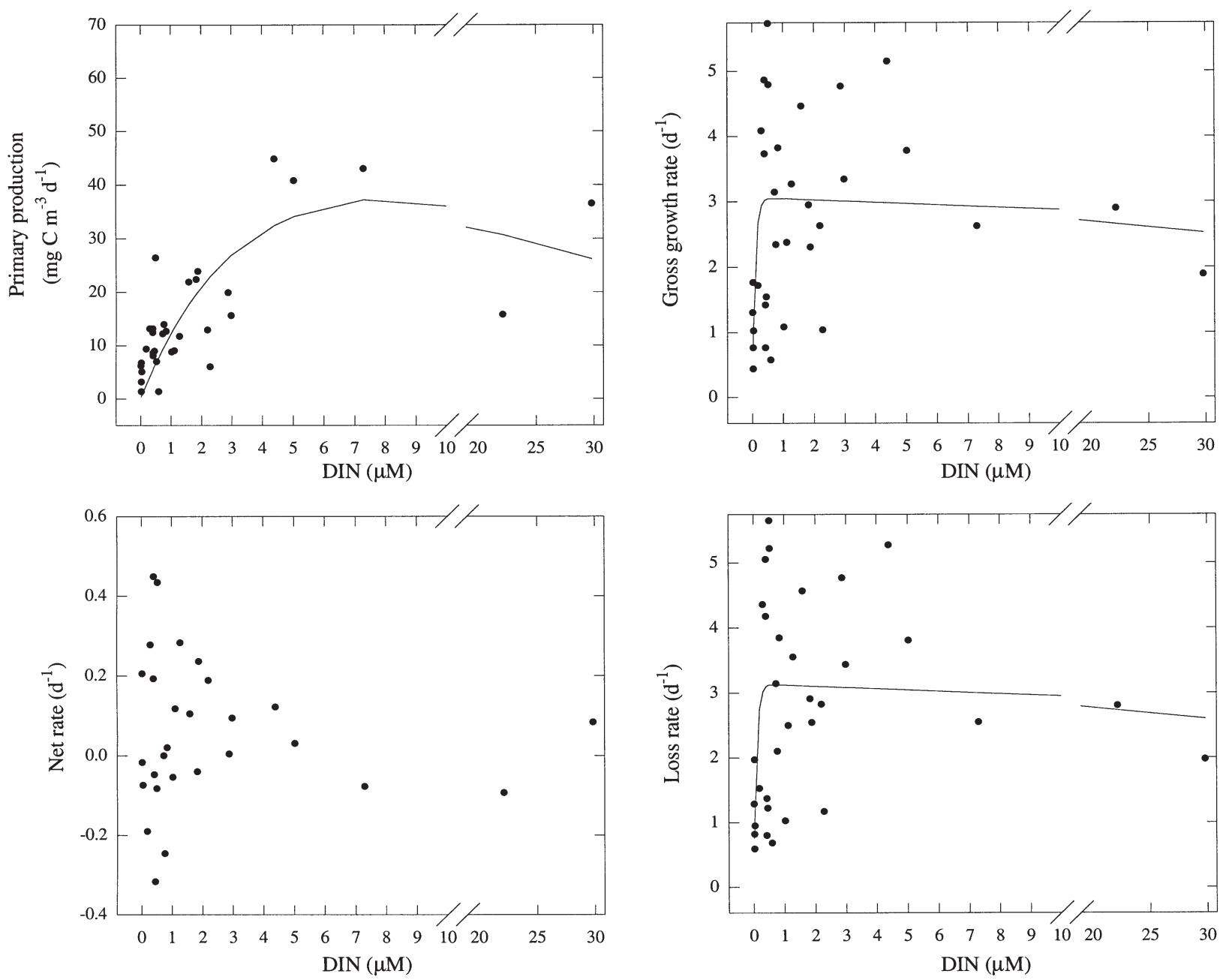

Fig. 4. Synechococcus. Primary production, growth, loss and net rates along the range of ambient DIN measured in the different mesocosm units in the Bay of Blanes. Data were fitted with the hyperbolic tangent models of P-I curves (Jassby \& Platt 1976, Platt et al. 1980)

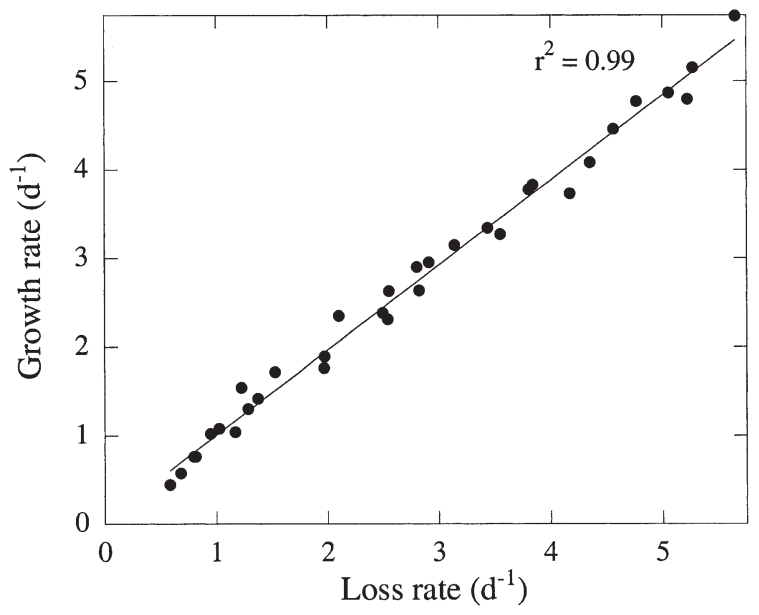

Fig. 5. Synechococcus. Relationship between growth and loss rates during the mesocosm experiments in the Bay of Blanes. Solid line indicates the fitted linear regression line tion in coastal sites subject to high anthropogenic nutrient inputs in the Mediterranean (e.g. Adriatic Sea, Magazzù et al. 1989a, Magazzù \& Decembrini 1995), and similar to the mean picophytoplankton primary production reported in brackish Mediterranean eutrophic environments (Acosta et al. 1988, Magazzù et al. 1989b). The mean growth rates of Synechococcus at the onset of the experiment (about $1.17 \mathrm{~d}^{-1}$ ) was consistent with previously reported summer values (Agawin et al. 1998, Jacquet et al. 1998).

Growth rates and primary production of Synechococcus rapidly increased in response to nutrient additions reaching values 2 to 4 times (up to $5 \mathrm{~d}^{-1}$ ) that of the highest nutrient loading observed in the summer in the Bay of Blanes. The stimulation of growth and production of Synechococcus preceded that of microphytoplankton, which have been found to respond after only 1 wk of nutrient additions (cf. Duarte et al. 2000a). 
The early response of growth and primary production of Synechococcus to nutrient additions provides evidence that the population was nutrient-limited in the ambient waters, supporting previous claims of nutrient-limited picoplankton growth in other Mediterranean systems (Vaulot et al. 1996, Thingstad et al. 1998). This rapid response (4 d) suggests that nutrientlimited Synechococcus can respond very rapidly to high nutrient pulses, which is consistent with the occurrence of Synechococcus bloom in areas subject to episodic nutrient pulses (Phlips et al. 1999). Synechococcus was however unable to sustain the increased growth rate as nutrient inputs progressed further. Growth rates only increased subsequently in the absence of experimental nutrient additions, where DIN gradually accumulated (Duarte et al. unpubl.).

Marine picophytoplankton are believed to require very low nutrient concentrations $\left(0.4 \mathrm{nM} \mathrm{P}\right.$ and $7 \mathrm{nM} \mathrm{Ni}_{\text {; }}$ Chisholm 1992, Thingstad 1998, Agawin et al. 2000) to sustain the fastest growth rates found in nature (ca $2 \mathrm{~d}^{-1}$, Agawin et al. 1998). This is a consequence of the high specific affinity for nutrients associated with their small size (Chisholm 1992, Thingstad 1998). Results of our mesocosm experiment showed increased growth rates of Synechococcus as an early response to nutrient enrichment. This suggests that Synechococcus can be nutrient-limited despite being well adapted to growth at fast rates in oligotrophic conditions (Donald et al. 1997). Here, results showed that with in situ nutrient addition, Synechococcus growth can reach up to $5 \mathrm{~d}^{-1}$, consistent with reports that, in oligotrophic waters in general, growth rates of phytoplankton can reach up to 6.6 doublings per day (or $4.5 \mathrm{~d}^{-1}$ ) (Goldman et al. 1979). Although experiments on the response of natural Synechococcus populations to nutrient enrichment at mesocosm scales (level III experimental design, Hecky \& Kilham 1988) are very rare in oligotrophic regions, microcosm experiments (level II experimental design, Hecky \& Kilham 1988) showed that the experimental addition of phosphorus to Mediterranean populations of Synechococcus resulted in an increase of their division rates in spite of already fast growth rates under P-limited conditions (Vaulot et al. 1996). These empirical results suggest that the very low nutrient thresholds for nutrient-saturated growth of Synechococcus derived from theory underestimate the growth requirement of natural populations. The results obtained here indicate nutrient-saturated growth to be reached at an ambient DIN concentration of $0.25 \mu \mathrm{M}$. Hence, the Synechococcus population in the bay must have been nutrientlimited at the onset of the experiment, when DIN concentrations were $<0.05 \mu \mathrm{M}$. The values estimated here are consistent with the suggestion that picophytoplankton growth is saturated at ambient nutrient concentrations of $>0.2 \mu \mathrm{m} \mathrm{N}$ (Cochlan \& Harrison 1991).
The 2 most used growth kinetic models used in plankton ecology (i.e. the Monod 1942 and Droop 1968 models) do not account for growth inhibition at higher nutrient concentrations. Here we adapted the model of Platt et al. (1980) which in our data set characterized photo-inhibition to describe the growth inhibition of Synechococcus at relatively high DIN levels $(>8 \mu \mathrm{M})$. Although this may be the first report of growth inhibition of Synechococcus at high nutrient concentrations, there has been evidence of growth inhibition of diatoms at high ammonium concentrations $(>200 \mu \mathrm{M})$ and saturating nitrate concentrations (Hillebrand \& Sommer 1996). The inhibition of Synechococcus growth at relatively high DIN levels suggests that the high ambient ammonium concentrations achieved in the mesocosm of these experiments may be toxic to Synechococcus, which should be tested further.

The early response, of increase in population size with increased nutrient loading, is indicative of limitation of Synechococcus biomass in the Bay of Blanes. As population size is a result of the interplay of growth and loss rates (Lehman 1991), the early response of increase in population size with increased nutrient loading indicates a lag between Synechococcus growth and loss rate responses during the early phase of the experiment. The early net population increase of Synechococcus (Fig. 1) was due to increased growth with increased nutrient loading since the grazing rates across the gradient of nutrient loading remained comparable (Fig. 3). Indeed, heterotrophic nanoflagellates, which are suggested to be the main grazers for picophytoplankton (Stockner \& Antia 1986, Šimek et al. 1997), only showed increased biomass 1 wk after nutrient inputs were initiated (after $8 \mathrm{~d}$ of nutrient addition, the biomass of heterotrophic flagellates increased, on

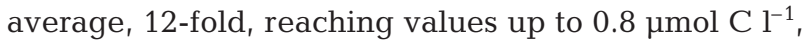
cf. Duarte et al. 2000b, in this issue). However, ciliates (Sherr et al. 1989), which are suggested to also graze on picophytoplankton, did not show an increased response to nutrient additions (ciliate biomass during the study remained negligible, ranging from 0.01 to $0.17 \mu \mathrm{mol} \mathrm{Cl}^{-1}$, cf. Duarte et al. 2000b). The increase in heterotrophic nanoflagellate abundance half way through the experiment (cf. Duarte et al. 2000b) at the highest nutrient loadings coincided with the increased grazing losses and decline of Synechococcus abundance, despite their high growth rates at the highest nutrient loadings. The relatively large cell size $(1.8 \mu \mathrm{m}$ cell diameter) of Synechococcus (characteristic of dividing cells) may also explain the high grazing pressure on Synechococcus at the highest nutrient loading during the middle phase of the experiment, possibly due to selective grazing of this larger cell size by consumers (Monger \& Landry 1992). Towards the end of the experiment, a relaxation of grazing pressure on 
Synechococcus resulted in a general increase of Synechococcus abundance (at Day 16) across the mesocosm units. The occurrence of relatively smaller Synechococcus cells (1.1 $\mu \mathrm{m}$ cell diameter) towards the end of the experiment, coincident with reduced grazing pressure in the mesocosm units, suggests grazing selectivity against smaller sized cells (Monger \& Landry 1992). Despite the low growth rates of Synechococcus at the highest nutrient loadings towards the end of the experiment, their abundance increased, possibly due to decreased grazing pressure on Synechococcus at this time. The population dynamics of Synechococcus during the experiment, therefore, could also have resulted from changes in grazing rates on the population, as suggested by the negative correlation observed between grazing rates and Synechococcus population size (Fig. 3). The grazing rates reported here may be underestimated because the zooplankton community was dominated by gelatinous organisms also able to graze in the pico-size fraction (gelatinous organisms were present during the study, on average, from 364 to 1331 individuals $\mathrm{m}^{-3}$ in the mesocosm units, Duarte et al. unpubl.). This grazing, even though by heterotrophic flagellates (Stockner \& Antia 1986, Šimek et al. 1997) has been suggested to be the main loss process for picophytoplankton (grazing rates reported here, on average, accounted $>50 \%$ of the calculated loss rates during the first 2 wk of the experiment). Mortality due to lysis from viral attack or exposure to possibly toxic levels of nutrient concentrations (Reynolds 1984) might also have been an important loss process, particularly towards the end of the experiment when grazing rates only accounted for $13 \%$ of the calculated loss rates. Phytoplankton display high lysis rates in the summer in the NW Mediterranean (Agustí et al. 1998). However, phytoplankton lysis rates decreased with increased nutrient loading (Agustí et al. 1999 unpubl.), which may also have contributed to the increased abundance of Synechococcus towards the end of our experiment.

In summary, the early response of growth and primary production of Synechococcus with nutrient enrichment provides evidence that the growth of the population was nutrient-limited in the Mediterranean bay studied during the summer of 1997. Synechococcus was however, unable to sustain increased growth rate as high nutrient inputs continued, showing growth inhibition at relatively high DIN levels $(>8 \mu \mathrm{M})$. Growth of Synechococcus was saturated at approximately $0.25 \mu \mathrm{M}$ DIN, consistent with the previous observation of their dominance in waters with $<1 \mu \mathrm{m}$ $\mathrm{NO}_{3}+\mathrm{NO}_{2}$ (Agawin et al. 2000). Growth and loss rates showed a very similar response to nutrient concentrations, although fluctuations in the population dynamics of Synechococcus in response to nutrient enrichment were observed, derived from lags between the responses of growth and loss rates to increased nutrient inputs. Growth rates showed a faster response to increased nutrients than grazing rates did, which depend on a sufficiently enhanced carbon flow in the food web to allow the growth of the grazing population. Nutrient pulses in the oligotrophic ocean must, therefore, also yield increases in Synechococcus population size preceding the re-establishment of balanced growth and grazing rates.

Acknowledgements. This study was funded by the European Commission under the ELOISE programme 'COMWEB' (contract MAS3-CT96-0045), and the Spanish Commission for Science and Technology (CYTMAR 96-2383-CE). N.S.R.A. was supported by a fellowship from the Agencia Española de Cooperación Internacional. Our sincere gratitude to A. Lucea for the nutrient analyses, and X. Moran and J. Gasol for help in ${ }^{14} \mathrm{C}$ scintillation counting.

\section{LITERATURE CITED}

Acosta PL, Bruni V, Decembrini F, Giuffrè G, Maugeri TL (1988) Distribution and activity of picophytoplankton in a brackish environment. Prog Oceanogr 21:129-138

Agawin NSR, Duarte CM, Agustí S (1998) Growth and abundance of Synechococcus sp. in a Mediterranean bay: seasonality and relationship with temperature. Mar Ecol Prog Ser 170:45-53

Agawin NSR, Duarte CM, Agustí S (2000) Nutrient and temperature control of picoplankton to phytoplankton biomass and production. Limnol Oceanogr 45(3):591-600

Agustí S, Satta MP, Mura MP, Benavent E (1998) Dissolved esterase activity as a tracer of phytoplankton lysis: evidence of high phytoplankton lysis rates in the NW Mediterranean. Limnol Oceanogr 43:1836-1849

Chisholm SW (1992) Phytoplankton size. In: Falkowski PG, Woodhead AD (eds) Primary production and biogeochemical cycles in the sea. Plenum Press, New York, p 213-237

Chisholm SW, Olson RJ, Zettler ER, Waterbury J, Goericke R, Welschmeyer N (1988) A novel free-living prochlorophyte occurs at high cell concentrations in the oceanic euphotic zone. Nature 334:340-343

Cleveland WS (1979) Robust locally weighted regression and smoothing scatterplots. J Am Stat Assoc 74:829-836

Cochlan WP, Harrison PJ (1991) Kinetics of nitrogen (nitrate, ammonium and urea) uptake by the picoflagellate Micromonas pusilla (Prasinophyceae). J Exp Mar Biol Ecol 153: 129-141

Donald KM, Scanlan DJ, Carr NG, Mann NH, Joint I (1997) Comparative phosphorus nutrition of the marine cyanobacterium Synechococcus WH7803 and the marine diatom Thalassiosira weissflogii. J Plankton Res 19:1793-1813

Droop MR (1968) Vit. B12 and marine ecology: IV. The kinetics of uptake, growth and inhibition in Monochysis lutheri. J Mar Biol Assoc UK 48:689-733

Duarte CM, Agustí S, Agawin NSR (2000a) Response of a Mediterranean phytoplankton community to increased nutrient inputs: a mesocosm experiment. Mar Ecol Prog Ser 195:61-70

Duarte CM, Agustí S, Gasol P, Vaqué D, Vázquez E (2000b) The effect of nutrient supply on the biomass distribution of planktonic communities: an experimental test on a 
Mediterranean littoral community. Mar Ecol Prog Ser 206: 87-95

Goldman JC, McCarthy JJ, Peavy DG (1979) Growth rate influence on the chemical composition of phytoplankton in oceanic waters. Nature 279:210-215

Hecky RE, Kilham P (1988) Nutrient limitation of phytoplankton in freshwater and marine environments: a review of recent evidence on the effects of enrichment. Limnol Oceanogr 33:796-822

Hillebrand H, Sommer U (1996) Nitrogenous nutrition of the potentially toxic diatom Pseunitzschia pungens f. multiseries Hasle. J Plankton Res 18:295-301

Jacquet S, Lennon JF, Marie D, Vaulot D (1998) Picoplankton population dynamics in coastal waters of the northwestern Mediterranean Sea. Limnol Oceanogr 43:1916-1931

Jassby AD, Platt T (1976) Mathematical formulation of the relationship between photosynthesis and light for phytoplankton. Limnol Oceanogr 21:540-547

Landry MR, Hassett RP (1982) Estimating the grazing impact of marine micro-zooplankton. Mar Biol 67:283-287

Laws EA, Redalje DG, Haas LW, Bienfang PK, Eppley RW, Harrison WG, Karl DM, Marra J (1984) High phytoplankton growth and production rates in oligotrophic Hawaiian coastal waters. Limnol Oceanogr 29:1161-1169

Lehman JT (1991) Interacting growth and loss rates: the balance of top-down and bottom-up controls in plankton communities. Limnol Oceanogr 36:1546-1554

Magazzù G, Decembrini F (1995) Primary production, biomass and abundance of phototrophic picoplankton in the Mediterranean Sea: a review. Aquat Microb Ecol 9: 97-104

Magazzù G, Bruni V, Decembrini F, Panella S (1989a) La produzione primaria del picoplankton fotosintetico nei mari italiani. Oebalia 4:463-478

Magazzù G, Decembrini F, Pulicanò G (1989b) Andamento temporale della biomasa e della produzione primaria del picofitoplancton nel complesso lagunare de Faro e Ganzirri (Messina). Nova Thalassia 10:135-155

Monger BC, Landry MR (1992) Size-selective grazing by heterotrophic nanoflagellates: an analysis using live-stained bacteria and dual-beam flow cytometry. Arch Hydrobiol Beih Ergeb Limnol 37:173-184

Monod J (1942) Recherches sur la croissance des cultures bacteriennes. Hermann et Cie, Paris

Peña MA, Lewis MR, Harrison WG (1990) Primary productivity and size structure of phytoplankton biomass on a transect of the equator at $135^{\circ} \mathrm{W}$ in the Pacific Ocean. DeepSea Res 37:295-315

Phlips EJ, Badylak S, Lynch TC (1999) Blooms of the picoplanktonic cyanobacterium Synechococcus in Florida Bay, a subtropical inner-shelf lagoon. Limnol Oceanogr 44: 1166-1175

Editorial responsibility: Otto Kinne (Editor), Oldendorf/Luhe, Germany
Platt T, Gallegos C, Harrison WG (1980) Photoinhibition of photosynthesis in natural assemblages of marine phytoplankton. J Mar Res 38:687-701

Reynolds CS (1984) The ecology of freshwater phytoplankton. Cambridge University Press, Cambridge

Satta MP, Agustí S, Mura MP, Duarte CM (1996) Gross planktonic primary production in the Bay of Blanes (19921994). In: Duarte CM (ed) Seasonality in the Blanes Bay: a paradigm of the northwest Mediterranean littoral. Publ Espec Inst Esp Oceanogr 22:31-38

Schlüter L (1998) The influence of nutrient addition on growth rates of phytoplankton groups, and microzooplankton grazing rates in a mesocosm experiment. J Exp Mar Biol 228:53-71

Sherr EB, Rassoulzadegan F, Sherr BF (1989) Bacterivory by pelagic choreotrichous ciliates in coastal waters of the NW Mediterranean Sea. Mar Ecol Prog Ser 55:235-240

Šimek K, Hartman P, Nedoma J, Pernthaler J, Springmann D, Vrba J, Psenner R (1997) Community structure, picoplankton grazing and zooplankton control of heterotrophic nanoflagellates in a eutrophic reservoir during the summer phytoplankton maximum. Aquat Microb Ecol 12: 49-63

Sokal RR, Rohlf FJ (1981) Biometry, 2nd edn. WH Freeman and Company, New York

Stockner JG, Antia NJ (1986) Algal picoplankton from marine and freshwater ecosystems: a multidisciplinary perspective. Can J Fish Aquat Sci 43:2472-2503

Thingstad TF (1998) A theoretical approach to structuring mechanisms in the pelagic food web. Hydrobiologia 363: $59-72$

Thingstad TF, Zweifel UL, Rassoulzadegan F (1998) P limitation of heterotrophic bacteria and phytoplankton in the Northwest Mediterranean. Limnol Oceanogr 43:88-94

Vaulot D, Partensky F, Neveux J, Mantoura RFC, Llewellyn CA (1990) Winter presence of prochlorophytes in surface waters of the northwestern Mediterranean Sea. Limnol Oceanogr 35:1156-1164

Vaulot D, LeBot N, Marie D, Fukai E (1996) Effect of phosphorus on the Synechococcus cell cycle in surface Mediterranean waters during summer. Appl Environ Microbiol 62:2527-2533

Waterbury JB, Watson SW, Valois FW, Franks DG (1986) Biological and ecological characterization of the marine unicellular cyanobacterium Synechococcus. In: Platt T, Li WKW (eds) Photosynthetic picoplankton. Can Bull Fish Aquat Sci 214:71-120

Welschmeyer NA, Lorenzen CJ (1984) Carbon-14 labeling of phytoplankton carbon and chlorophyll a carbon: determination of specific growth rates. Limnol Oceanogr 29: $134-145$

Submitted: October 12, 1999; Accepted: May 18, 2000

Proofs received from author(s): October 9, 2000 